\title{
Orhan Peker'in Resimlerinde Lekeci Anlatım
}

\author{
Doç. Şemsettin Edeer
}

\section{Öz}

Bu araştırma, Orhan Peker'in sanata bakış açısı, ele aldığı konuları ve leke kavramıyla birlikte yapıtlarının Türk Resim Sanatındaki yeri ve önemini ortaya koymaya yöneliktir. Bu kapsamda konunun aydınlatılabilmesi ve daha anlaşılır kılınabilmesi için, yazarların, sanatçıların, araştırmacıların farklı görüşlerine ve bu görüşlerin karşılaştırmalarına yer verilmiştir. Orhan Peker, kendi kişisel ve özgün anlatım yollarıyla resimlerinde, gündelik hayatın sıradanlığını Doğu-Batı sentezinde farklı sunuşlarıyla gözler önüne sermiştir. Yöresel özelliklere de yer verdiği resimleri, lekeci-anlatımcı bir karakter taşır. Sanatta önemli olanın "içtenlik" olduğunu savunan sanatçı, belli temalar çerçevesinde birbirinden çok farklı konu ve tekniklere yönelmiş ve bu çalışmalarını farklı görünümler halinde gerçekleştirmiştir.

Anahtar Kelimeler: Orhan Peker, Resim, Leke, On’lar Grubu, Halk Sanatı

\section{TACHIST EXPRESSION IN ORHAN PEKER'S PAINTINGS}

\begin{abstract}
This study aims to reveal the role and importance of OrhanPeker's view on art, the subjects he dealt with, the concept of tachism and his works of art in Turkish painting. Within this framework, in order to clarify the subject and to make it more understandable, it was aimed to include different views of writers, artists, and researchers and comparisons of these views in the study. OrhanPeker revealed mediocrity of everyday life in his paintings through his original expression with east-west synthesis. His paintings, in which he also included local characteristics, feature a tachist- expressionist character. The artist, who supported that the important thing in art was "sincerity", used subjects and techniques that are very different from each other within certain themes and performed these works in different perspectives.
\end{abstract}

Keywords: Orhan Peker, Painting, Tachism, Group On'lar, Folk Art

Doç. Şemsettin Edeer, Anadolu Üniversitesi, Eğitim Fakültesi, Güzel Sanatlar

Eğitimi Bölümü, Yunus Emre Kampüsü Tepebaşı / Eskişehir.

e-posta: sedeer@anadolu.edu.tr Tel: +90 22233505 80/3528 


\section{Giriş}

Türk resim sanatında, lekeci anlayışta, bir mihenk taşıdır Orhan Peker. Yaşadığı döneme yön verebilmiş, ardında bıraktığı yapıtlarla, sonraki kuşakları da etkisi altına alabilmeyi başarmış büyük bir ustadır. Hangi alanda olursa olsun, bir sanatçının yaşadığı dönem koşulları ve yaşam öyküsü bilinmeden, yapıtlarını anlayabilmenin mümkün olamayacağı ortadadır. Bu nedenle ustanın yaşam öyküsüne minik bir büyüteç tutarak, eserlerini incelemeye çalışacağız.

Orhan Peker, 27 Mayıs 1927 tarihinde Trabzon'da doğar ve çocukluğu bu şehirde geçer. Babası tüccar olmasını istese de, Orhan Peker'in tercihlerinde, yayınevi sahibi büyükbabası Hamdi Başman Efendi daha etkin rol oynamıştır. Onun sanatsal yaşamının ilk yıllarında önemli bir yeri olan büyükbabasının kitapevinde pek çok kaynağa ulaşabilecek ve okuduklarıyla, kendine farklı bir yön çizmeye başlayacaktır. Aynı zamanda, bir müzisyen olan ablasının kocası Sıtkı Küçükerman'la kurduğu yakın ilişki, tüm yaşamı boyunca, müzikle olan bağlantısının başlangıcını oluşturur (Küçükerman, 1994).1942 yılında yatılı olarak Avusturya Sankt Georg lisesine kayıt olur. Okulda öğreneceği Almanca daha sonra sanat alanında yazılmış kitapları okumasında çok işine yarayacaktır.

İkinci Dünya Savaşı bitiminde yaşamında yepyeni ufuklar açacak olan Bedri Rahmi Eyüboğlu atölyesine, akademiye adım atar. Burada resim yapmak onun için bir tutku haline gelecektir. Bedri Rahmi atölyesinde Peker, değerli bir öğretmenin gözetiminde klasik sanatın, soylu geleneğinin ilkelerini içine sindire sindire yetişmiştir. Ne var ki Orhan Peker Antik kökenli Avrupa sanatını bilinçle incelerken Uzak Doğu sanatına, Çin ve Japon geleneğine de büyük ilgi duymaktaydı. Erol onun için " $\mathrm{O}$, akademiye başladığında ressamdı" der (Erol, 2002: 8).

Peker, 1947 yılında arkadaşlarıyla birlikte kurmuş oldukları On'lar grubunda kendi üslup ve anlayışılla 1952'ye kadar sanat etkinliklerini sürdürmüştür. Sanatçı, mezuniyet sonrasında İstanbul Şehir Tiyatrosunda yönetmen Max Meinecke'nin yanında tercüman olarak çalışmış ve1955 yılında onunla birlikte Viyana ve Paris'i ziyaret etmiştir.

Peker, 1965 yılında düzenlenen Devlet Resim ve Heykel Sergisi'nde birincilik kazanmasının ardından Madrid'e giderek şehirdeki sanat ortamını gözlemlemiştir. Aynı günlerde İspanyol ressam El Greco'nun portrelerinden birini kopyalamıştır. 1966 yılında Türkiye Çağdaş Ressamlar Cemiyeti'nce, "Yılın Ressamı" seçildi. Jüri, yılın sanatçısı olarak seçilmesinin gerekçesini, "Dikkati çeken, son yıllarda sürekli gelişme gösteren, kişisel üslubunda 
mahalliniteliklere desahip olanvebunu resimolanaklarıiçinde gerçekleştiren sanatçı" olması dolayısıyla bu ödüle layık görmüştür (Küçükerman, 1994: 13). TRT'nin düzenlediği resim yarışmasında Aşık Veysel portresiyle başarı ödülü almıştır. Daha birçok başarıya imza atan ve grafiksel çalışmalarla da uğraşan Peker, Almanya'daki Türk çocukları için hazırlanan Ağaca Takılan Uçurtma (1974), Metin Eloğlu'na ait Rüzgar Ekmek ve Çetin Öner'e ait Gülibik isimli kitapları da resimlemiştir.

Sanat yapmanın çağın gerçekleriyle örtüşmesi gerektiğine inanan Peker, estetik çalışmaların yanı sıra sosyal meselelerin de ciddiye alınması gerektiğini savunuyordu.

1950 sonrası sosyal siyasal ve ekonomik alanlardaki yeni oluşumlar şüphesiz sanat alanlarını da etkilemiş, yeni bir açıım ve çok yönlülük getirmiştir. İşçi-köylü sınıfına politik açıdan verilen önem, bu kesimin yaşamını ve doğasını sanata taşıyarak açık, anlaşıır, figüratif bir resim üslubunun benimsenmesi sonucunu getirmiştir. Anadolu insanı sanatın temel konusu olmuştur (Ersoy, 1998: 30).

Gelişen toplumsal gelişmelere paralel olarak çok yönlü bakış açısı ve anlayışlar çerçevesinde bireyselliğin önem kazanmaya başlaması, sanatçının insana bakışını, dolayısıyla figüratif resmi de etkilemiştir.

1960 başlarında toplum ve insana yönelen ilgi, resmin toplumsal iletişim yöntemlerinden biriolarak kavranması, figüratifyönden yenifigür araştırmalarını yoğunlaştırmıştır. Bu yıllarda somut kavramlar önem kazanmaya başlar. Yenifigüratif eğiliminde, Türk kültür tarihinde oluşmaya başlayan kavramsallaşma önemli etki yapmıştır. Türk figüratif resminde içerik yönünden, kişisel yönelimlerle ortaya çıkan bu gelişme, Türk resmini çağdaş yorumlara götürme yönünden önemli olmuştur (Gültekin, 1992: 21).

Orhan Peker, sadece resim değil, farklı alanlarda da çalışmalara katkı sağlar. İstanbul şehir tiyatrolarında dekor çalışmaları yürütmüş, Ankara'da ise, Turizm Bakanlığında afiş ressamı olarak görev almıştır. Ankara'da yaşadığı yıllarda, bir afiş sanatçısıyla yaptığı evliliği kısa süren Orhan Peker, daha sonra, 1976 yılında, yaşamının sonraki yıllarını geçireceği, Ayvalık'a yerleşmesine vesile olacak olan, Ayvalıklı, varlıklı bir hanım olan Gönül Karaca ile evlenir (Tansuğ, 1990: 28). Ayvalık deneyiminde ise bozkır manzaraları ve çeşitli hayvan figürlerini resimlerine konu olarak almıştır.

1969 yılında, Japonya'daki "EXPO-70" için açılan yarışmada Ragıp Buluç ile beraber birincilik ödülünü alan sanatçı, yaşadığı süre içinde, 
tutkuyla, bir yaşam tarzı olarak sanatı yaşayıp, pek çok eser üretmiş ve Türk sanatında yeni yetişen sanatçılara büyük bir yol gösterici olmuştur ve olmaya da devam ediyor. 11 Nisan 1978 tarihinde Akademideki Bedri Rahmi Eyüboğlu Galerisinde güvercin temalı son sergisini açar. Bu sergiden kısa bir süre sonra, 1978 yılında İstanbul'da, çok erken bir yaşta hayata gözlerini kapamıştır.

\section{Leke Kavramı}

Önemli görünmesi bakımından leke kavramının özelliklerini birkaç genel çizgi ile belirtmek gerekli olacaktır. Nesnelerin anlamının ve güzelliğinin önce konturlarda arandığını dile getiren Wölfflin, konturlar yani çizgiler, “(...) gözü sınırlar boyunca ve kenarları izleyerek görmeye yöneltilir, kitleyi görüşteyse, dikkat kenarlardan ayrılır, kontur gözün izlemesi gereken yol olmaktan az ya da çok çıkar ve ilk izlenim, nesnelerin lekeler halinde algılanması olur" diyerek çizgi ile leke arasındaki algı farklılığını ortaya koyar (Wolfflin, 1990: 31-32)."(...)Sanatın çizgiyle başladığı ve formların çizgi ile ifade edilmesinden başlayarak renk lekelerine gitmesi ve sonunda inşacılık, bütün sanat ekollerinde ve çağ üsluplarında açık olarak görülür. Öyle ki, bu gelişim olayını, bir kanun olarak bütün uygarlık sanatının gelişiminde görebiliriz" (Turani, 1992: 28).

Çizgi, figürü mekandan, fondan ayıracak kesin sınır çizgileri olarak, üstünlüğünü korurken, gölgesel (lekesel) bir anlatımda keskin sınır çizgilerinin ortadan kalkmasıyla ya da yumuşamasıyla, figürler mekanıyla bütünleşmeye başlar. Başka bir deyişle, çizgisel üslup resim üzerindeki figürlerini hareketsiz olarak sabitlerken, gölgesel üslupta, çizgilerin sınırlayıcı etkisinin ortadan kalkması ve konturların yumuşamasıyla, kütleler yüzey üzerinde bağımsız bir şekilde yayılıp birbirine bağıı lekeler oluştururlar. "Çizgisel üsluptaki ayırıcı etki yapan her biteviye belirli çizgiler, gölgeselde şekillerin birbirine bağlanmasını kolaylaştırmak için belirsiz sınırlar haline gelmiştir"(Wolfflin, 1990: 32-33).

"Leke, bir yüzey üzerinde, yüzeyin renk ve tonundan daha farklı renk ve tonda fark edilen, daha küçük bir yüzey olarak tanımlanabilir" (Keser, 2005: 201).Parlak, ışıklı yüzeydeki karanlık bölge, koyu ile örtünmüş bölüm ya da karanlık bir yüzeydeki aydınlık bölge, açık ile örtünmüş bölüm, lekesel alan olarak adlandırılır. Resimlerdeki renklerle onların tonları arasındaki karşılıklı ilişkiler ve bağıntılar, resmin etkileyici özelliğini doğrudan etkiler.

Resimsel biçimlendirmede en önemli ögelerden biri de nesnelerin ışığı yansıtma güçlerine göre görmek ve gösterebilmektir. Bu konuda Cemal: "Gerek resim sanatında gerekse grafik sanatlarda gölgelendirme ya da ışık 
ve gölge dağılımı figürlerin ve nesnelerin cisimselliklerini belirgin kılmak için başvurulan bir yoldur" demektedir (Cemal, 2013: 225). Doğal nesneler, içinde bulundukları ısıklılık durumuna göre, mesafe farklılıklarını da ortaya koyan bir takım planlar ve yüzey biçiminde algılanırlar; bu sözünü ettiğimiz planlar, yüzeyler nesnenin görsel biçimini oluşturur. Işığın geliş açısına göre açık, orta ve koyu değerlerde oluşan bu planlar, nesnenin üçüncü boyutta görsel olarak algılanmasını sağlar. Renklerinde ışığı yansıtma biçimi, diğer doğal nesnelerde olduğu gibi farklılıklar içerir. Yine bu üç değer üzerinden, yani açık, orta ve koyu değerler üzerinden açık renk, koyu renk olarak belirlenirler. Lekesel anlamda düşündüğümüzde, bir rengin leke etkisi, o rengin renk şiddetinden daha etkilidir. Çünkü nesnenin yansıttığı ışığın parlaklık dereceleri karşısında tepki veren göz, rengin çeşitliliğinden önce açık-koyu etkisini algılar, seçer. Bir rengin daha açık ya da daha koyu olması, rengin kendisini değil, o rengin ışık etkisi altındaki 'tonu'nu oluşturmasıdır.

Bir takım anlatım olanakları yaratan bu lekeler, sanatçının duyarlıığı ile plastik dilin gereklerine uygun olarak bir araya getirildiklerinde oldukça güçlü ifadelerin izleyiciye iletilmesini sağlarlar. Aslında leke etkisi, figür ile fonu arasında kurulan bağıntıyla açıklanabilir. İki ışıklı alan arasındaki kontrastın (zıtlığın) şiddeti, yani açık ile koyu değerler arasındaki farkın artması belirginliği artırdığı gibi güçlü çağrışımlar yaparak ifadeyi de güçlendirir. Bu zıtlıklar, resim yüzeyinde vurgulu alanların yaratılmasında ve izleyicinin bu vurgulu alanlara yönlendirilmesinde etkili görevler üstlenirler.

\section{Orhan Peker'in Sanata Bakış Açısı}

Orhan Peker, kendi kuşağının başarılı, yaptıklarıyla ön plana çıkabilen bir sanatçısı olarak, doğaya ve insana dair gözlemlerini, son dönem çalışmalarında olduğu gibi, ilk dönem resimlerinde de olgunluk dönemine ulaşmış bir sanatçının resimlerindeki atmosferi yakalayabilen çalışmalar ortaya koymuştur. Ankara'da Ulus Meydanında gözlediği itfaiyeciler onun önemli bir çalışma grubunu oluşturur. Onun siyahı kullanma biçimi en belirgin şekilde ittfaiyeciler serisinde kendini gösterir. Daha sonraki çalışmalarında da siyahın ve siyah tonlarının, lekeler halinde resimlerine hâkim olduğu görülür. Sanatında içtenliği ve samimiyeti her zaman bir ilke olarak kabul eden Peker: "Resim sanatında her şeyden önce içtenliğe inanırım. Sanatçı topluma bu yoldan varabilir. Sanatçı her şeyden önce içinden geldiği gibi çalışmalıdır. Sürekli ve içtenlikli bir çalışma, sanatçının dilini yapar" (Erol, 2002: 11) diyerek, bu konudaki düşüncesini ifade eder. Doğaya farklı bir bakış yönelten Peker, doğa karşısındaki duyarlılığını şu şekilde dile getirir: 
“ (...) Açık-koyu resmin temelinde bu ilkin ezilmeyen dış konturların içinde gücünü sonradan kanıtlayan çekirdeği aramak gerek. Çarpıcı (ekspresif) bir leke bu çekirdeği taşımıyorsa, inandırıcı olamaz. Başlangıçta, uzun bir süre çalıştığım Kara Kuşlar, Kargalar dizisinde bu iç ürpertiyi sezmek olasıdır. Ardından gelen(mandalar) dizisi de aynı tutkunun örnekleriydi. Ve sonra torbalı atlar dizisi geldi, giderek hayvanın yaşantısına eğilmek onun-neredeyseiç dünyasına bakmak başlamıştı bende. Hüzün ve acıyla kasılmış gözlerinde bu atların ne düşündüğünü anlıyor gibiydim. Üzerlerine atılmış örtülerde de ayrıca masklar, bağıran, öfkeli yüzler görür gibiydim. Yani, elime geçirdiğim her koyu lekenin yaşantısını, devinimini saptıyordum. Kendi görüntüleri de aynı içeriğin örnekleridir. İster kendi kitlesel açık koyularında, ister dış mekanda olan ilişkisinde görünsünler, sonuç değişmiyordu" (Tansuğ, 1990: 28-29).

Peker, soyut resme hiçbir zaman girmemesine karşın özellikle fon ve mekân algısında soyutlamaya yönelik resimlerinde doğal, samimi ve içten yaklaşımıyla yaşamın özünü, anlamını yakalamaya çalışır. Onun sanatı için, yaşam deneyimlerinden kaynaklanan yaratma eyleminin sınırsız olanakları içerisinde, denemelere yönelik çalışmalarının sanatsal dönüşümüdür diyebiliriz. Hayatını kazanmak amacıyla sanat dışı, tercümanlık, memuriyet gibi işlerde çalışmış; bu işlerin katı disiplininden hoşnut olmamasına karşın sanatında disipline inanan ve çalışmalarına yansıtan bir sanatçı olmuştur. Hiçbir değer, onun resim yapma isteminden daha önemli olmamıştır. Giray, onun sanatçı kimliğinden bahsederken, "Tüm kurallara başkaldıran, tüm öğretileri kendi bilincinin imbiğinden süzen, tüm korkuları hiçe sayan, beğenilmek ve beğendirmek adına yapılan bütün kolaycılıkları reddeden özgür bir Peker kimliğini ortaya koyuyor" (Giray, 2014).

Orhan Peker, Almanya, İspanya ve Avusturya gibi Avrupa'nın çeşitli ülkelerinde sanat deneyimini artırmak amacıyla müzelerde araştırma ve incelemeler yapmış, 1956 yılında Salzburg yaz Akademisinde Oscar Kokoscha'yla birlikte çalışmıştır. Akademik çizimlerin katı kurallarına karşı durduğu, ironik, acı, korku ve tedirginlikleri yansıtan izlenimci portrelerini burada çalışmıştır. Pek çok yapıtın orijinalinden kopyalar yaparak ifadenin resimsel anlatımlarda ne kadar etkili ve önemli oluğunu yeniden keşfetmiştir. Aynı zamanda boyanın dokusal etkisini de pekiştirmiştir. Özellikle İspanya hükümetinin bursuyla gittiği Madrit'teki Prado Müze'sindeki El Greco başta olmak üzere Velazquez, Goya gibi diğer ustaların resimlerini dikkatli bir gözlemle inceleyerek kopyalarını yapar, etkilenir ve bu üç ustaya karşı büyük hayranlık duyar. Peker, "Kopya yapmak hem duygu hem de teknik bakımdan faydalı oluyor. Tabii zorla değil de aşkla yapılırsa" (Küçükerman, 1994: 30) sözlerinde olduğu gibi, kopya yapmanın önemini her defasında 
vurgulamıştır. Sık sık gittiği boğa güreşlerinde çizmiş olduğu desenlerini defterinde toplamış ve 1995 yılında Yapı Kredi Yayınları tarafından "ispanyol Defteri" adı altında yayınlanmıştır.

Çalışmalarını diziler halinde oluşturan Orhan Peker'in baskı sanatlarına duyduğuilgiden kaynaklı, açık-koyulekelerinyanyanagelerekoluşturdukları uyumundan faydalanarak, soyutlamaya yönelen çalışmalar ortaya koyduğu görülür. Çizgiler yok olmuş, yerini lekelere bırakmıştır onun resimlerinde. Lekelerin ön planda yer aldığı baskı resimlerinde kargalar, mandalar, güvercinler, atları konu alan gravür plakalarında baskılar yapmıştır.

Peker, nesnelerin somut görüntülerinden yola çıkarak, soyutlama düzeyine giden lekeci bir anlatımı ortaya koymuştur. Onun için leke resimsel biçimlemede vazgeçilmez bir öge olarak yer alıyordu. Hemen hemen tüm resimlerinde lekenin görsel algıda yaratacağı güçlü etkisini çözümlemeye çalışmıştır. Görsel algının çözümlemelerine bağlı olarak, figüratif istiflemelerle soyut renk lekelerinin dengesini kurmaya çalışmıştır. Bunu yaparken de koyu-açık lekelerin oluşturduğu bir düzen içerisinde özgün, duyarlı bir yorum düzeyine ulaşmıştır. Renk değerlerini açık-koyu etkileri dokusal özellikleri içinde eriten ve anlatımcı ögelere oldukça geniş yer veren anlayışı sergilemiştir. Resimlerinde ilk bakışta biçimler ayrıntılardan uzak bir bütün olarak algılanır. Bu bütünün algılanmasını güçleştirecek olan tüm karmaşık çizgiler, lekeler bir bir ayıklanarak, biçim, yeni bir düzen içerisinde soyut bir leke tadında yeniden var olur. Fon-mekân, onun son resimlerinde belirgin bir şekilde kendini gösteren plastik endişesini yansıtır. Nesnel olmayan ama yaşanılabilir bir dış gerçekliğe ait, ayrıntıların görünmediği, hissedilebilir gizli bir mekân anlayışının bir sonucudur. Onun resimleri, dış gerçeklikten çok resmin kendi gerçekliğine dönüşür. Bu da yeni bir resimsel düzenlemeyle yeni bir gerçekliği yakalama endişesinden kaynaklanır. Saflık ve sadeliğin söz konusu olduğu resimlerinde yeni anlatım ve içerikler onun üslubunun temel niteliklerini oluşturur. Bu aynı zamanda, resimde fazlalıkları, yapaylıkları bir kenara atarak yapılan arındırma ve öze eriştirme çabası olarak görülebilir. "Onun bakışı, nesnelerin özlerine dokunmaksızın biçimleri değiştirir" (Sıtkı, 1980: 16). Onun resimleri, bütünü oluşturan parçaları görmek için gözü daha dikkatli bakmaya çağııır ve fark edilmeyi beklerler.

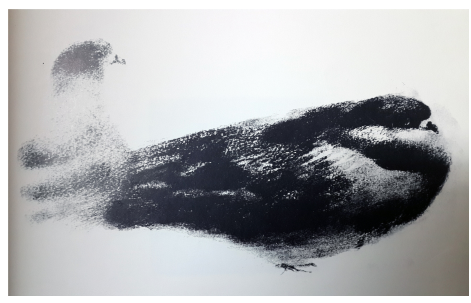

Resim 1: Orhan Peker, Güvercinler, 1977 Kağıt Üzerine Karakalem,17x27cm. 
Orhan Peker'in gerek insan ve hayvan, gerekse ölü doğa resimleri, hüzün, yalnızlık ve insanın içine işleyen bir tutunamamışlık duygusu uyandııı izleyende. Hayvanlara olan özel ilgisi, onun çalışmalarında hayvanları konu edinmesine neden olmuştur. Onun hayvan figürleri insana ait özellikler taşır. Lekelerle oluşturduğu bu biçimlemelerde insani duyguların yansıları belirir.

\section{Orhan Peker'in Resimlerinde Konu}

Orhan Peker'in resimlerine aktardığı çalışma konularını, diziler halinde ortaya koyduğunu görürüz. Resimlerinde kediler, atlar, horozlar, çiçek sepetleri, itfaiyeciler, mandalar, kısacası hayata dair pek çok şey görürüz. Ancak, hepsi de hayatın gerçekliğinden kopmuş, kendisine dair çizgileri kaybolmuş ve yaşam içinde, insanın belleğinde yer alan soyutlanmış biçimlere dönüşmüşlerdir.

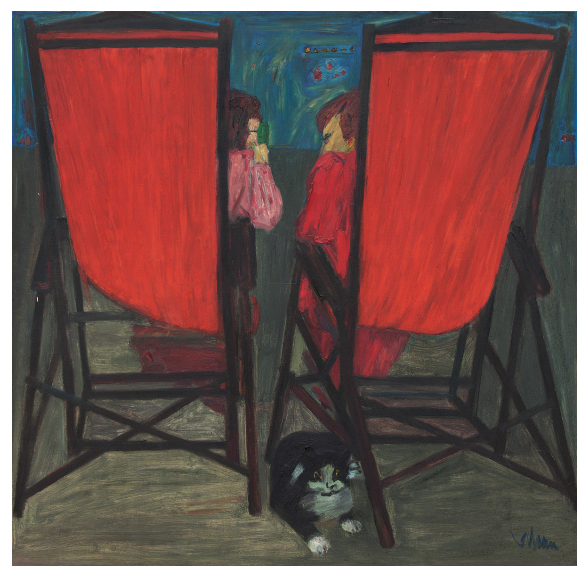

Resim 2: Orhan Peker, Özden, Komşu ve Başka, 1969 Tuval Üzerine Yağı Boya, 135x136cm.

Doğaya duyulan hayranlığın ve yaşanmışlı̆̆ın bir göstergesi olarak ele aldığı oldukça geniş bir yelpazeye sahip konuları arasında portreler, ağaçlar, manzaralar, hayvanlar, (atlar, kediler, horozlar, koçlar, mandalar, güvercinler, kargalar vb.) kır çiçekleri, gecekondular, itfaiyeciler, kapılar, karpuzlar, çay bardakları gibi gündelik yaşamın izlekleri yer alıyordu. Resimlerini, insanı güneşin çocuğu olmaya zorlayan kuşlar, çiçekler, atlar, kediler, dinlenme salıncakları; en soğuk renklerinde bile yaşama sevinci fışkıran iyimser bir dünyanın malı olmuş bir bütünlügü olarak gören Sıtkı, onun resimlerindeki konu seçimine yaklaşımını şu şekilde ifade ediyor: "Resim konusu olarak, o canının istediği birinden öbürüne geçer, sonra gene ona döner"(Sıtkı, 1980: 22). 


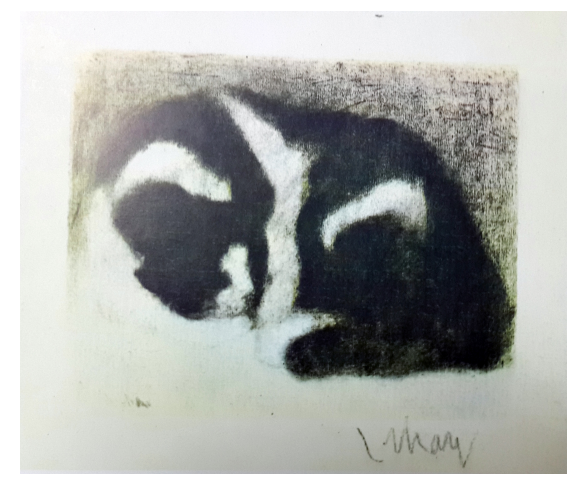

Resim 3: Orhan Peker, Kıvrılmış Kedi, 1971, Kağıt Üzerine Yağlı Pastel, 35,5x51,5cm.

Çoğu zaman görmeden yanından geçip gittiğimiz basit nesneler onun resimlerinde yaşamın derin içselliğini yansıtır.Yorgun atları, üşümüş güvercinleriyle bir sessizlik anlatır onun resimleri. Yaşamını sürdürdüğü çatı katını atölye ortamına dönüştüren Peker, bu atölyenin duvarlarına kuşlar, mandalar ve diğer konuların yer aldığı resimlerle birlikte itfaiyeciler serisini de asmaya başlamıştır. Figüratif deformasyonların öne çıktığı bu resimler, lekenin anlatım değerlerini yansıtmasının yanında yarattığı ifadeci anlayışın da örnekleri arasında yer almaktadır. Orhan Peker'in "Ittfaiyeciler" i ile Matisse'in "Dans ve Müzik" adlı resmiyle bağ kuran Giray, Ankara Samanpazarı'daki büyük yangından etkilenen Peker'in yangına koşan erleriyle, Matisse'in otantik müzik eşliğinde dans eden kadınları arasındaki ritmik armoniyi ilişkilendirmektedir. Matisse' in "Dans ve Müzik" resminde dans eden kadınların oluşturduğu kompozisyonu duyumsayan Peker'in resminde, hortumlarını kavrayan itfaiye erlerinin koşma eylemiyle, gövdelerini öne arkaya atarak adeta dans etmektedirler (Giray, 2014).

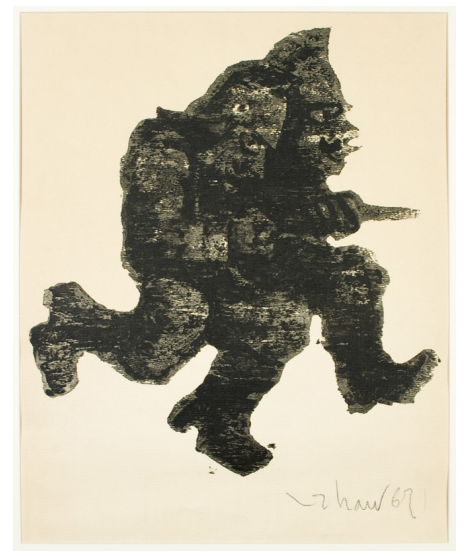

Resim 4: Orhan Peker, İtfaiyeciler, 1967, Ağaç Baskı,72x52 cm. 


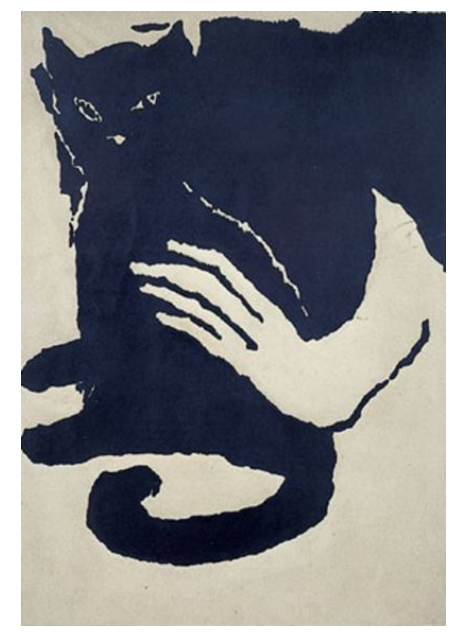

Resim 5: Orhan Peker, Kedi, 1954, Serigrafi, 25.5x18cm.

\section{Onlar Grubu İçinde Orhan Peker}

1947 yılında aralarında Orhan Peker'inde bulunduğu Bedri Rahmi Eyüboğlu öğrencileri, "Onlar Grubu" adı altında sanatsal etkinliklerde bulunmak üzere bir araya gelmişlerdir. "Ülke sanatı için olumlu sonuçlar veren Onlar Grubu sergileriyle ve çalışmalarıyla, "yöresel ve ulusal" çıkışlı anlayışların benimsendiği bir döneme girilir. Onlar Grubu için "yöresellik" ve "özgünlük" en önemli iki unsurdur" (Eyüboğlu, 2011: 19). Bedri Rahmi Eyüboğlu etrafında toplanan bu sanatçıların bir araya gelme nedenleri olarak Yarar-Dal: "(...) Türk resminde Doğu-Batı bireşimini yaratmak olarak nitelendirilebilecek sanatsal kaygı, diğeri ise yeni mezun öğrencilere kendilerini tanıtma ve sanat ortamında bir yer sağlama kaygıSı olarak değerlendirilebilir" (Yarar-dal, 1984: 4) demektedir. Bedri Rahmi Eyüboğlu'nun yardımları ve koruyuculuğu altında ülkenin tüm kültür ögelerinden yararlanmayı hedef olarak almışlardır. Renkçi ve lekeci anlatımlarıyla halk sanatına yönelmeleri bu sanatçıların ortak noktalarını oluşturuyordu.

Halk mı sanatçıya yükselmelidir yoksa sanatçı mı halka inmelidir, tartışmasında işin zorluklarına rağmen yan yana, baş başa yürümelerinin gerekliliğine inanan Bedri Rahmi Eyüboğlu, sanatçının halkı gözeterek sanat yapmasının önemi ve gerekliliğini vurgulamaktadır (Eyüboğlu, 2011: 99). Bedri Rahmi Eyüboğlu da öğrencilerine bu düşünceler doğrultusunda eğitim vermeye çalışmış, gerek kendi, gerekse öğrencileri Türk sanatına çıkış noktası olarak yerel olanı, kilim, halı, minyatür, işleme ve Türk motiflerini ele almış ve bu çerçeve kapsamında yoğun bir şekilde çalışmalarını ortaya 
koymuşlardır. Kendi insanımız ve kendi toprağımıza ait değerleri ön plana çıkarma çabası içinde olmuşlardır.

Türk resminde renkçi-lekeci figürasyon eğiliminde, Bedri Rahmi Eyüboğlu atölyesinde yetişmiş bir grup sanatçı bulunmaktadır. Bunlar 1950'lerde Bedri Rahmi'nin Fov sanat anlayışından etkilenen ve renkle birlikte leke öğesini de başarıyla değerlendiren Turan Erol, Orhan Peker ve Avni Arbaş'tır. 1960'larda, figüratif-soyut karşıtlığında resme bir çözüm getirmeye çalışan Turan Erol, Orhan Peker, lekeci yorumla özgün yapıtlar vermişlerdir. Her iki sanatçının bu yıllarda yoğunlaşan yöresellik anlayışına, lekeci bir eğilim içinde yaklaştıkları görülmektedir (Gültekin, 1992: 21).

Orhan Peker'in yöreselliğe bakışı doğaya salt bağlılık olarak değil, ele aldığı konunun karakteristik özelliklerine indirgeyen bir yalınlaşmayla açıklanabilir. Görüntünün bu genel karakteristiklerinin dışında her hangi bir fazlalığa yer vermiyor. Aynı zamanda ele aldığı görüntünün doğal yapısından uzaklaştırmadan onu bulunduğu ortamı içerisinde değerlendirir.

\section{Aşık Veysel Portresi Üzerine Bir İnceleme}

Renkçi-Lekeci anlayışla çalışmalar ortaya koyan Orhan Peker'in "Aşık Veysel" portresi, sanatçının en bilinen eserlerinden biridir. Ozanı, yaşadığı ortamın gerçekliğini arka plana yansıtarak resmetmiştir. Anadolu'nun uçsuz bucaksız bozkırına karşıık, üst kısımda yer alan, yine uçsuz bucaksız mavi gökyüzü birbirini tamamlar nitelik gösterir. Arkadaki çalıklıklar, bozkırdaki iklim tipine uygun olarak, cılız ve bünyesinde fazla renk barındırılmadan resmedilmiştir. Orhan Peker'i sanatta yüksek bir yere oturtan da, işte bu az renkle büyük işler başarabilmesindeki gizemdir. Ne ki onun resimlerine bakan bir kişi, bu resimlerin renkten yoksun olduğunu aklına dahi getirmez.

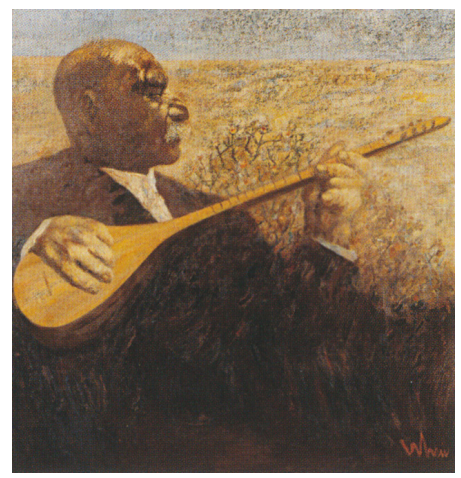

Resim 6: Orhan Peker, Aşık Veysel, 1971, Tuval Üzerine Yağlıboya, 151x151cm. 
Veysel'in resme aktarılmasında, duyarlı bir anlatım göze çarpar. Bağlamanın titreşen tellerinden yükselen sesle birlikte ozanın kapanan gözleri, gerçekte görmeyen gözlerini ifade ederken, "gönül gözüyle" nasıl da bakabildiğini, bizlere anlatmak ister gibidir.

Elinde tuttuğu bağlama, yansıyan ışıkla birlikte ön plana çıkmış, izleyicinin resme baktığında ilk algıladığı şey bağlama olmuştur. Vurgulanmak istenenin, halk sanatı ürünlerinden türküler olduğu böylelikle, çarpıcı bir şekilde belirtilmiştir.

\section{Sonuç}

Çağdaş Türk Resim sanatında “özgünleşme" yolunda 1940'lı ve 1950'li yıllar önemli bir süreç olarak karşımıza çıkmaktadır. Bu süreç içerisinde sanata bakışı ve yapıtlarıyla Orhan Peker'in kayda değer bir rolünün olduğunu söylememiz gerekmektedir. Aynı konunun çeşitlemeleri olarak karşımıza çıkan temalı resim dizilerinde, Doğu'nun görünenin arkasındaki anlama yönelik çağrışımları ile Batı'nın biçimsel plastiğinin kaynaşmış halini görebiliriz. Sıradan nesneler ve günlük hayatın içinden çekip çıkardığı konuların lekesel düzenlemeleriyle, duyguları, yalnızlığı, bunalımı, acıyı, sevgiyi özgün ve duyarlı anlatımlarıyla adeta yeniden yaratmıştır.

Peker, halk sanatını temel kaynak olarak alan Onlar Grubunun anlayışı içerisinde, sanatı halktan kopuk ve ayrışmış olmaktan kurtarıp, halka ulaştırabilmenin yollarını aramıştır. Bu görüşten yola çıkarak sanatın evrenselliği ilkesini de bir tarafa bırakmadan, doğu ve batı sanatlarını harmanlayarak, birbirine yakınlaştırmayı amaç edinmiştir. Grup içinde etkin görev alan Orhan Peker, daha akademiye girdiği ilk yıllarda dahi bilgisi ve yeteneğiyle dikkat çekmiştir. İlk dönem resimleriyle son dönem resimleri arsında ustalık anlamında büyük farklar gözlenmez. Az renk kullanarak, yalın ve basit konu seçimleriyle, lekesel anlayışla eserler ortaya koymuştur. Yakaladığı resimsel etkileri ve soyutlamalarıyla, gerek kendi dönemi içindeki sanatçıları gerekse ardıllarını etkileyebilmeyi başarmıştır. Böylelikle Onlar Gurubu denildiğinde, ilk akla gelen isimlerden biri olan Peker, sanat dünyasındaki kalıcılığını yakalamış ve onu hak etmiştir. 


\section{Kaynakça}

Cemal, A. (2013). Lanetlenmiş Ağustos böcekleri, Istanbul: Can Yayınları.

Erol, T. (2002). Orhan Peker 1927-1978 Ara Güler'den Orhan Peker, İstanbul: Milli Reasürans Sanat Galerisi.

Ersoy, A. (1998). Günümüz Türk Resim Sanatı, (1950'den 2000'e), İstanbul: Bilim Sanat Galerisi.

Eyüboğlu, S. (2011). Mavi ve Kara, IV. Baskı, İstanbul: Türkiye Iş Bankası Yayınları.

Gültekin, G. (1992). Batı Anlayışında Türk Resim Sanatı, Türkiye Ziraat Bankası, KültürSanat Etkinlikleri.

Keser, N. (2005). Sanat Sözlüğü, Ankara: Ütopya yayınevi,

Küçükerman, Ö. (1994). Ressam Orhan Peker, İstanbul: Milli Reasürans Galerisi.

Sıtkı, Ş. (1980). Orhan Peker, İstanbul: Fotografik Ofset Yayınları.

Tansuğ, S. (1990). Türk Resminde Yeni Dönem, II. Basım, İstanbul: Remzi Kitapevi.

Turani, A. (1992). Dünya Sanat Tarihi, 4. Basım, İstanbul: Remzi Kitapevi.

Wolfflin, H. (1990). Sanat Tarihinin Temel Kavramları, (Çev. Hayrullah Örs), 3. Basım, İstanbul: Remzi Kitapevi.

Yarar-Dal, E. (1984). On'lar Grubu, Yeni Boyut Plastik Sanatlar Dergisi, (24), 4.

\section{Internet Kaynakları}

Giray, K.(18 Aralık,2014).Web: http://www.antikalar.com/v2/konuk/konuk1 109.asp

\section{Görsel Kaynakları}

Resim 1: Orhan Pekerin anısına, Meteksan'ın 10 numaralı kitap yayını, No: 2071 (Ocak 1984)

Resim2: http://www.yenicikanlar.com.tr/orhan-pekerin-ozden-komsu-ve-baskave-fahrelnissa-zeidin-cerkes-gelini-adli-eserleri-3-haziranda-beyaz-muzayededesatisa-cikiyor-29872 (06.0cak.2015)

Resim 3: Orhan Pekerin anısına, Meteksan'ın 10 numaralı kitap yayını, No: 2071 (Ocak 1984)

Resim 4: http://csmuze.anadolu.edu.tr/eser/peker-orhan (06.Ocak.2015) 
Resim 5: http://renkdelisi.tr.gg/ORHAN-PEKER.htm( 06.Ocak.2015)

Resim 6: http://www.besiktascagdas.com/orhanpeker.html (06.Ocak.2015) 